\title{
Influences of Climate Change on Tourism Development in Small Pacific Island States
}

\author{
Franziska Wolf $1, *\left(\mathbb{D}\right.$, Walter Leal Filho ${ }^{1,2}{ }^{\mathbb{D}}$, Priyatma Singh ${ }^{3}$, Nicolai Scherle ${ }^{4}$, Dirk Reiser ${ }^{5}$, John Telesford ${ }^{6,7} \mathbb{D}^{\circ}$, \\ Ivana Božić Miljković ${ }^{8}$, Peni Hausia Havea ${ }^{9}$, Chunlan $\mathrm{Li}^{10}{ }^{10}$, Dinesh Surroop ${ }^{11}$ and Marina Kovaleva ${ }^{1} \mathbb{C}$
}

1 Research and Transfer Centre Sustainable Development and Climate Change, Hamburg University of Applied Sciences, 21033 Hamburg, Germany; walter.leal2@haw-hamburg.de (W.L.F.); marina.kovaleva@haw-hamburg.de (M.K.)

2 Department of Natural Sciences, Manchester Metropolitan University, Manchester M15GD, UK

3 School of Science and Technology, The University of Fiji, Lautoka, Fiji; priyatmas@unifiji.ac.fj

4 FOM Hochschule für Oekonomie und Management (FOM), 80335 Munich, Germany; nicolai.scherle@fom.de

5 Faculty of Society and Economics, Rhine-Waal University of Applied Sciences, 47533 Kleve, Germany; dirk.reiser@hochschule-rhein-waal.de

6 School of Continuing Education, T. A. Marryshow Community College, St George's, Grenada; j.n.telesford@rgu.ac.uk

7 Institute of Island Studies, University of Prince Edward Island, Charlottetown, PE C1A 4P3, Canada

8 Faculty of Business Studies, Singidunum University, 11000 Belgrade, Serbia; ibozicmiljkovic@gmail.com

9 Live \& Learn Tonga, Nuku'alofa, Tonga; ilaisiaimoana@yahoo.com

10 Center for Geopolitical and Strategic Studies \& Institute for Global Innovation and Development \& School of Urban and Regional Sciences, East China Normal University, Shanghai 200062, China; 15598022233@163.com

11 Department of Chemical \& Environmental Engineering, University of Mauritius, Réduit 80837, Mauritius; d.surroop@uom.ac.mu

check for updates

Citation: Wolf, F.; Filho, W.L.; Singh, P.; Scherle, N.; Reiser, D.; Telesford, J.; Miljković, I.B.; Havea, P.H.; Li, C.; Surroop, D.; et al. Influences of Climate Change on Tourism Development in Small Pacific Island States. Sustainability 2021, 13, 4223. https://doi.org/10.3390/su13084223

Academic Editor: Stephen Royle

Received: 10 March 2021

Accepted: 8 April 2021

Published: 10 April 2021

Publisher's Note: MDPI stays neutral with regard to jurisdictional claims in published maps and institutional affiliations.

Copyright: (c) 2021 by the authors. Licensee MDPI, Basel, Switzerland. This article is an open access article distributed under the terms and conditions of the Creative Commons Attribution (CC BY) license (https:/ / creativecommons.org/licenses/by/ $4.0 /)$.

* Correspondence: franziska.wolf@haw-hamburg.de

Abstract: Tourism-related carbon dioxide $\left(\mathrm{CO}_{2}\right)$ emissions are a central driver of anthropogenic climate change. At the same time, climate change has both direct and indirect impacts on tourism, varying from damages of tourist assets due to extreme weather events, to losses of biodiversity. Small island developing states (SIDS) heavily depend on international tourism as a source of revenue and income. Therefore, much could be gained by assessing the vulnerability of the SIDS tourism sector and by identifying measures that may assist these islands in their sustainable adaptation efforts. Against this background, this interdisciplinary paper provides a review of tourism development and the implications of its emissions on the global climate, linked with observed and projected influences of climate change in the Pacific region, to explain the growing vulnerability of the overall sector, with a particular focus on SIDS tourism. A description of the effects of COVID-19 on international tourism and its consequences for SIDS complement the analysis. Case studies of two Pacific islands present some evidence of current climate impacts, underscoring the multiple risks small island nations and their tourism sectors face. The paper concludes by stating that some measures may be prioritized by decision-makers, so as to increase the resilience of a transforming tourism sector in SIDS.

Keywords: tourism; $\mathrm{CO}_{2}$ emissions; climate impacts; Pacific region; Solomon Islands; Tonga

\section{Introduction}

Even though tourism science has been dealing intensively with the topic of climate change for about 25 years, there remains a pressing need for further research to support the necessary transformation of the tourism sector to a sustainable undertaking [1]. The number of scientific publications has shown a clear upward trend in the last one and a half decades, with a sharp increase in the last eight years, including key adaptation literature on climate change affecting tourism [2-5], adaptation and carbon mitigation [6,7], policy $[8,9]$, and sustainability $[10,11]$. Substantial research gaps exist, there seems to be a geographical bias on the developed part of the world, methodological weaknesses in 
determining tourism-related greenhouse (GHG) emissions along the value chain, and issues regarding equity $[12,13]$. Counteracting the geographical bias by its focus on small island developing states (SIDS), this interdisciplinary paper aims to provide a review of tourism development and the implications of its global emissions on the global climate, and links it with possible and already seen influences of climate change in the Pacific region to explain the growing vulnerability of the overall sector, with a particular focus on SIDS tourism in the Pacific region. The effects of the SARS-COV2 pandemic on international tourism and its consequences for the national development of Pacific SIDS complement the analysis. Case studies of two Pacific Islands present some evidence of current climate impacts, grounding the multiple risks small island nations and their tourism sectors face in the literature.

Operationally, the well-known, risk-based conceptualization of vulnerability resembles the analytic lens for this paper [14]. Linking disaster risk management and climate change adaptation, this framing can support the identification and prioritization of adaptation options and helps to strengthen resilience to changing conditions [15]. For this reason, this paper documents some of the observed impacts of climate change in two less researched, low-lying Pacific Island countries (PICs), i.e., Tonga and the Solomon Islands. This is complemented with future climate projections and linked with the development and challenges of international tourism, a sector that is a key pillar of national development in these islands. These islands are seldom investigated, so a concrete contribution to the literature is provided here.

This paper is structured as follows: following the introduction, Section 2 explains the methodological approach pursued. Section 3 reviews characteristic features of the tourism sector and its related GHG emissions, highlighting the shortcomings of current emission monitoring to explain why a paradigm shift is needed to substantially reduce the carbon footprint of tourism. Section 4 explores some direct and indirect impacts of climate change on touristic attractions and provides broader evidence from the Pacific region, with Section 5 presenting evidence of current climate impacts in two Pacific SIDS that increasingly impact tourism development. This paper concludes by stating some general measures that may be prioritized by decision-makers in order to increase the resilience of a transforming tourism sector in SIDS to a changing climate, minimize adverse impacts, and reduce island vulnerability.

\section{Materials and Methods}

This study addresses the need for more research on climate change and tourism with a focus on developing countries that heavily rely on tourism as source of national income, i.e., SIDS in the Pacific region. Here, slow-onset phenomena like sea-level rise (SLR) as well as rapid onset events like tropical cyclones and storm surges represent substantial disaster risks for sectoral development and, consequently, income generation, poverty reduction, and human well-being. Church et al. [16] project the magnitude of SLR to be three times greater compared to the global level. However, the climate change related threats in the Pacific region, which is characterized by its environmental and cultural diversity, are still not fully understood despite more than three decades of scientific research; climate projections for the islands comprise inherent uncertainties, and climate impacts may vary throughout the region [17-19]. Combined with exploring the effect of the global pandemic on the overall development of international tourism and linking global trends with local realities of two Pacific SIDS, this study attempts to offer interdisciplinary insights into current and future vulnerability in the western Pacific region.

The methodological approach pursued in this paper entailed a qualitative review of the literature on climate change and tourism, including regional perspectives, complemented by purposive sampling of climate impacts observed in two Pacific SIDS (see Figure 1), reflecting local realities, via an extensive climate change research and information network. These countries, Tonga and the Solomon Islands, have been chosen for two main reasons:

- They provide clear examples of two less assessed PICs which heavily rely on tourism. 
- They may exemplify the multi-fold impacts of climate change on the tourism sector of PICs.

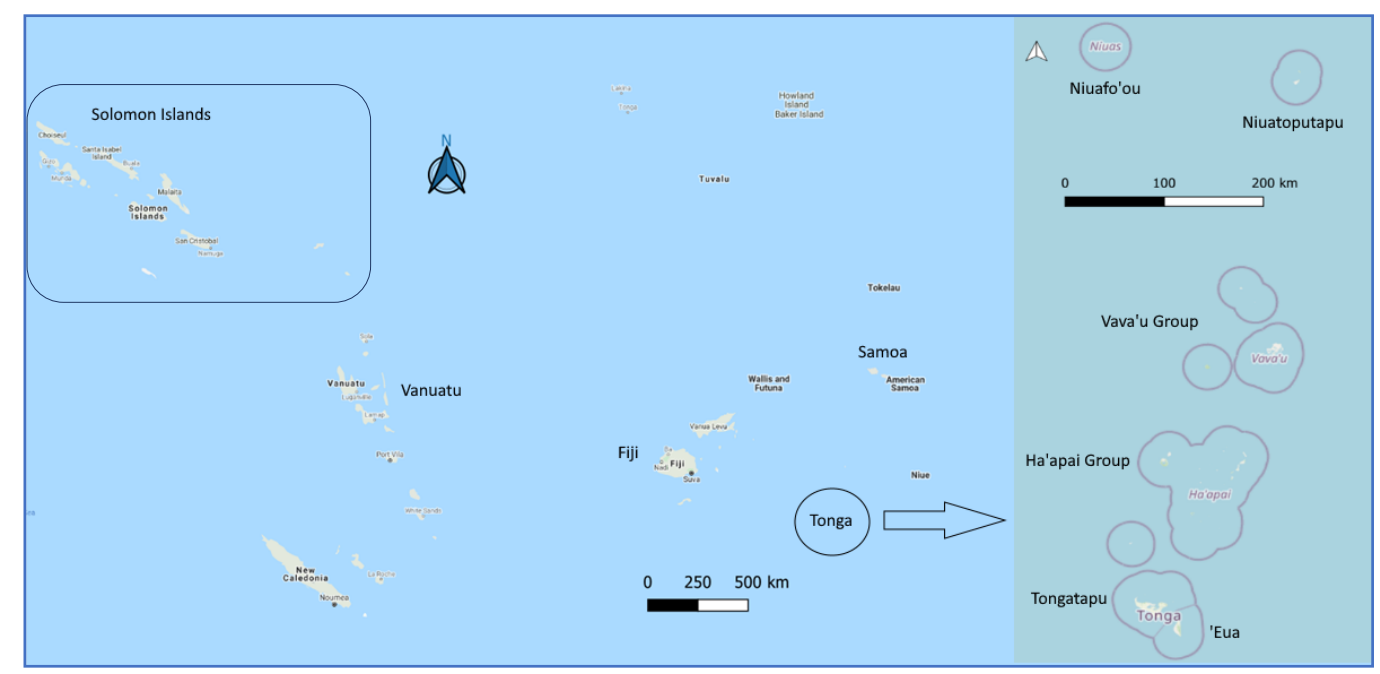

Figure 1. Schematic map of the Pacific regions showing Tonga, Solomon Islands, and other Pacific Island countries (PICs) in the region. Source: Authors.

While the review of key scientific tourism literature revealed current gaps in research that can inform the sustainable development of tourism-dependent small island nations, the researchers applied a convenience sampling technique for literature collection of the case studies which resulted in consolidated evidence of already observable climate impacts on tourism and, consequently, implications for sustainable national development in Tonga and the Solomon Islands.

The study has a limitation in the sense that it is limited to two distinctive PICs, reporting on trends that cannot be generalized for the region. Yet its value resides in the fact that it identified some of the key issues and problems at stake, and it also identified how these are related to economic trends that can also be observed elsewhere in the region. The challenge remains to clearly attribute the distinctive impacts of global phenomena (such as climate change and the pandemic) to local levels as available data (especially in the Pacific region) may not be fine-grained enough. Therefore, the results must be viewed with caution, and further climate research is needed to foster a greater understanding of its impacts on a regional and island-level.

Further economic research is also required to generate reliable and valid data from the relevant destinations, so as to calculate and document the exact monetary value of the damages of climate change on tourism. The nexus between climate change and economic parameters is generally not taken into account. Against this background, this particular topic offers substantial research potential.

\section{Global Tourism Sector Development}

Before the onset of the SARS-COV2 pandemic, the global tourism industry showed continued growth, yet future mitigation measures, as well the global pandemic, may influence this path of success. For the ninth year in a row, tourism growth outpaced world economic growth at a rate of $3.5 \%$ vs. $2.5 \%$ [20]. In 2019, the sector represented an industry that accounted for $10.3 \%$ of the global gross domestic product [21]. Rising global and regional tourist arrivals and receipts further substantiate the evidence of tourism's marked contribution to economic growth and development. The growth in both tourism arrivals and receipts suggests an increase in not only the number of trips, but also the amount of spending at the destinations, e.g., for accommodation, road transportation, and water sport equipment. The steady growth in these matrices during the period 2010-2019 is depicted in Figure 2. 


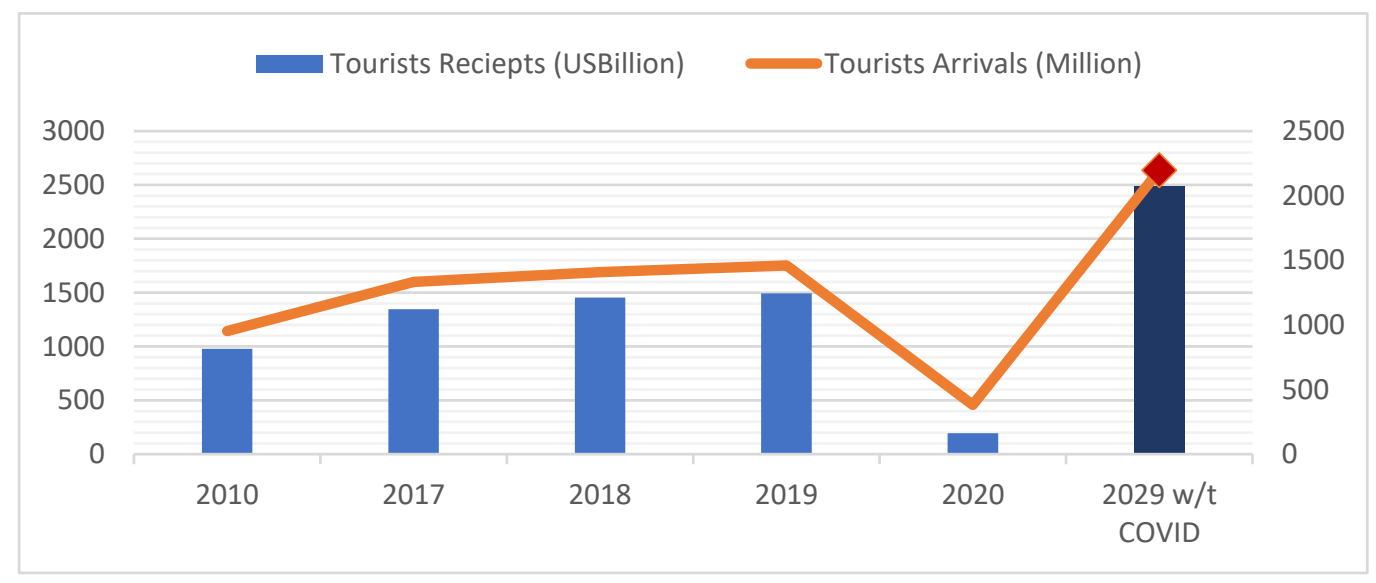

Figure 2. Global tourist arrivals in millions of tourists, right axis, and receipts in billions of United States dollars, left axis. Source: Authors, using data from [21-23].

For developing countries, tourism provides employment and income for their populations. For SIDS, tourism as a "postwar insular growth engine" [24] (p. 363) is an indispensable pillar of economic development [25]. In 2019, SIDS recorded about 44 million international tourist arrivals, corresponding to earnings of USD 55 billion in export revenues [26]. In PICs, tourism is especially pivotal for poverty alleviation and offers opportunities for achieving broader development goals, such as those regarding infrastructure and employment [27]. The Pacific region showed a $4.9 \%$ increase of tourist arrivals between 2007 and 2017, with the largest portion attributed to all-inclusive, enclavic resorts, and cruise ship passengers [28] (p. 444). Harrison and Pratt [29] identified a split of Pacific tourism destinations into islands mainly attracting leisure tourists (e.g., Fiji, Tahiti, Vanuatu, etc.) and islands that are visited mainly by businessmen, development aid workers, and consultants (e.g., Solomon Islands, Papua New Guinea) or friends and relatives (e.g., Tonga, Samoa, Kiribati etc.). Besides the high dependency on tourism and the high susceptibility to climate change impacts, PICs are also considered highly vulnerable to pandemics due to their connectivity to/from and between/within island nations, their fragile health systems, as well as adverse social and economic impacts of outbreak responses [30], even though, for example, the Caribbean can somewhat rely on established regional support structures due to previous experiences of handling extreme weather events [31].

With the sudden onset of the COVID-19 pandemic in late 2019, tourism development was put on abrupt hold. Related travel bans and restrictions have been affecting the tourism industry at all levels. Gössling et al. [32] stated that tourism largely stopped in March 2020, heavily impacting the air travel, cruise travel, and the accommodation industries. Travel bans and associated restrictions decreased international arrivals by $74 \%$ and translated into a massive decline of tourism receipts from USD 1480 million in 2019 to approximately USD 194 million in 2020. According to World Tourism Organisation (UNWTO) estimates, it might take between two and a half and four years for international tourist arrivals to return to pre-COVID levels [23].

For SIDS in particular, the impact of the 2020 outbreak responses was dramatic: tourist arrivals dropped by $47 \%$, or 7.5 million visitors between January and April 2020, with Pacific and Caribbean SIDS performing slightly better than other SIDS regions [26,33].

Despite the dramatic decline linked to the closing of borders, travel bans, and national lock-down effects, and even though the industry acknowledged "unprecedented challenges and an existential threat for the travel and tourism sector from the impacts of the COVID-19 virus globally" [20] (p. 2), the main tourism bodies expect the growth of the sector to continue, albeit from a lower baseline. A "safe, secure and seamless end-to-end experience" [20] (p. 14) is promoted to regain ground and address concerns that may prevent touristic travelling, anticipating both a rebound of touristic travel and improvement of social and economic conditions. 
Tourism researchers, however, challenge the continuance of the previously pursued volume growth tourism model favored by the major tourism bodies [32]. Upcoming global $\mathrm{CO}_{2}$ mitigation measures, combined with increasing impacts of climate change on popular tourist destinations, may indicate a sustainable transformation to a more climate-friendly and environmentally-friendly endeavor. The "sensitivity and vulnerability of touristic destinations to weather and climate change also suggest that, as a result of climate change, the tourism industry will in turn undergo drastic future change and will need to adapt to increasing risk" [34] (p. 522). Where else will this be most urgent than in disaster-prone SIDS, some of which are already experiencing slow and rapid onset phenomena such as sea-level rise or severe and frequent weather events?

\section{Global $\mathrm{CO}_{2}$ Emissions from the Tourism Sector}

Tourism can be viewed as a high energy intensive industry with a significant contribution to global $\mathrm{CO}_{2}$ emissions. The Global Tourism Dashboard [35] offers evidence of the amounts and continued increase in total carbon dioxide emissions from global air and cruise transport. Transport to the respective destination has always been regarded as the most serious environmental impact caused by tourism, with leisure and tourism traffic accounting for almost $50 \%$ of the passenger kilometers travelled worldwide and around $90 \%$ of total energy consumption arising from travel to the holiday destination [36,37]. Figure 3 illustrates that a set of key sub-sectors associated with tourism accounts for those emissions which are expected to increase substantially in the future [38] (p. 396). The share of transport mode for inbound tourist arrivals in SIDS is even higher, with $59 \%$ of tourists arriving by air and $41 \%$ by water, mostly on cruise ships.

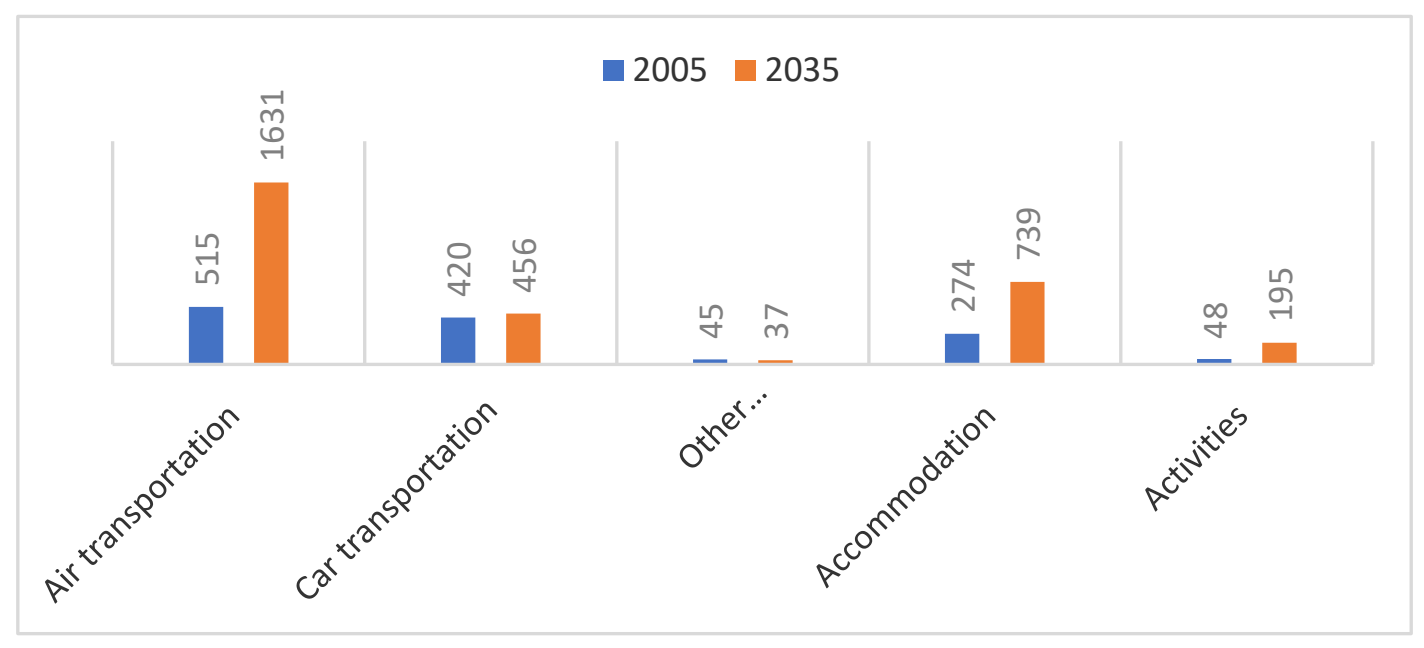

Figure 3. Emissions in $\mathrm{Mt}$ of $\mathrm{CO}_{2}$ from the key sub-sectors of tourism in 2005 and projected for 2035. Reproduced by Authors with data from [38].

To date, a central deficit of most scientific studies that dealt with the effects of tourism on climate is their limited focus on very specific sub-segments of the tourism service chain such as transport, excluding downstream tourism-relevant structures and activities. For example, a recent study assessed the heavy aviation carbon footprint of international air travel to the Canary Islands [39], yet to fully map the actual ecological footprint, the entire tourism life cycle needs to be screened, which ranges from obtaining information and booking the trip, to travel, accommodation, meals, and local activities, right through to departure. This translates into a significantly greater burden on the environment than previously assumed. Gössling and Peeters [40] (p. 642) explicitly call for "(...) a more complete analysis of the energy needed to maintain the tourism system (...) to include food and beverages, infrastructure construction and maintenance, as well as retail and services, all of these on the basis of a life cycle perspective accounting for the energy embodied in 
the goods and services consumed in tourism (...)". Current estimates, however, still do not capture this due to lack of data.

In addition, $\mathrm{CO}_{2}$ emissions per unit of different tourism activities can vary significantly (see Table 1). An analysis of the true costs of tourism, from travel to restaurants to souvenir purchases, disclosed that tourism-relevant structures and activities are responsible for $8 \%$ of climate-damaging greenhouse gases [34]. A multi-regional input-output analysis, which covered a total of 160 countries, showed that between 2009 and 2013 alone, tourism-induced GHG emissions rose from 3.9 to 4.5 gigatons of $\mathrm{CO}_{2}$ equivalents. GHG emissions from tourism-induced mobility have risen disproportionately with the growing prosperity of the source markets; with a gross domestic product of more than 40,000 US dollars per capita, an increase in prosperity of $10 \%$ led to an increase in the $\mathrm{CO}_{2}$ footprint from travel of up to $13 \%$. From a sustainability perspective, this is thought-provoking, considering that in many prospering source markets such as China or the so-called tiger states, tourism demand is increasing rapidly in view of an ever larger, more affluent middle class. The negative implications of largely globalized tourism structures are particularly relevant in the countries of the Global South that are heavily dependent on stationary sun-bathing tourism, and negative impacts from tourism are even more pronounced in island destinations that find themselves in a quandary as to how to alleviate the harmful environmental effects of large-scale inbound tourism whilst still maintaining acceptable levels of tourism-generated revenues [34] (p. 526).

Table 1. $\mathrm{CO}_{2}$ emissions in some of the tourism sectors.

\begin{tabular}{ccc}
\hline $\mathrm{CO}_{2}$ Emissions by Unit Average (Kg) & Min-Max & Estimated Global \\
\hline Emissions per cruise trip per passenger & $248-5610 \mathrm{~kg} \mathrm{CO}_{2}$ & $1.2 \mathrm{t} \mathrm{CO}_{2}$ \\
Emissions per guest night (accommodation) & $0.1-260 \mathrm{~kg} \mathrm{CO} 2$ & $13.8 \mathrm{~kg} \mathrm{CO}_{2}$ \\
Emissions per tourist per day (Ø trip; incl. & $15-492 \mathrm{~kg} \mathrm{CO}$ & $58 \mathrm{~kg} \mathrm{CO}_{2}$ \\
transp. + accom.) & $<0.001-9.3 \mathrm{t} \mathrm{CO}_{2}$ & $250 \mathrm{~kg} \mathrm{CO}$ \\
Emissions per trip, domestic + international &
\end{tabular}

Source: Authors after [40].

Due to the coupling between tourism and GHG emissions, projected exponential growth in tourism may result in associated growth in GHG emissions. In a business-asusual scenario, tourism-related $\mathrm{CO}_{2}$ emissions might increase by $130 \%$ by 2035 , with the largest contributions from air transport and accommodation [38] (p. 397).

Under optimistic assumptions, a rise in tourism-induced GHG emissions was thought to be limited to approximately 5 gigatons of $\mathrm{CO}_{2}$ equivalents by 2025 [31], otherwise climate-damaging emissions were likely to increase to 6.5 gigatons of $\mathrm{CO}_{2}$ equivalents. Against this background, it is not only a question of taking leave of the image of a 'white industry' cultivated over many decades, but also of initiating a paradigm shift, both in the destinations, and in the supranational tourism organizations. Widely viewed as an environmentally and socially responsible option for generating revenue, tourism development generally leaves a larger carbon footprint instead of reducing GHG emissions; compared to other means available for stimulating economic growth. Raising awareness of other means to stimulate economic growth and of the carbon-burden faced by tourism-stressed areas is crucial [34] (p. 526).

While raising awareness among key stakeholders is a first step, drastic mitigation measures will need to follow to substantially lower the GHG emissions resulting from tourism. The impacts of the lockdown serve as an illustrative example: Le Quéré et al. [41] assessed the temporary reduction in daily global $\mathrm{CO}_{2}$ emissions during the COVID-19 forced confinement and suggested that most changes in $\mathrm{CO}_{2}$ emissions were only temporary; economic, transport, and energy systems (the key ingredients of the tourism industry's 'product') did not undergo the transformative change required for a sustainable emission reduction. 


\section{Climate Change Impacts and the Tourism Sector}

Climate and climate-related factors play a crucial role in the selection of tourist destinations, and in determining the season, the time of travel, and the length of stay [42,43]. Depending on the geographical location of the tourist destination and the type of touristic activity, climate change may therefore influence, i.e., impact, the tourism sector as a whole, and tourism activities in particular, in many ways. These can be differentiated according to environmental, socio-cultural, and economic dimensions.

Regarding environmental impacts, for instance, the Himalayan ranges and the Tibetan plateau (high altitude regions in Asia) are currently facing glacier melting, glacier floods, and lake outbursts [44]. Furthermore, increased temperatures in some Middle Eastern countries have led to water shortages and increases in the frequency of heat waves, resulting in a decrease in tourism [45]. Winter tourism that is dependent on snow cover at mountainous resorts has also been impacted by alterations in the snow cover [46]. Concerning coastal and island tourism, slow-onset phenomena such as sea-level rise (SLR) and the warming of oceans as well as short-onset events such as flooding, high waves, and extreme weather events affect coastal areas and related marine attractions.

Due to anthropogenic forcing, the global mean sea level is rising, and this rise is accelerating [47]. In 2019, the global mean sea level rose to $8.76 \mathrm{~cm}$ above the 1993 average, which resembles the highest annual average in the satellite record [48]. As sea-level rise is not uniform, it shows substantial regional variability, which, for example, leads to an intensified higher rise in the Western tropical Pacific Ocean [47] (p. 340). Some low-lying PICs have already disappeared [49-51]. Low-lying SIDS with long coastlines are susceptible to many impacts of global climate change; the inundation of low-lying coastal land, erosion of beaches and shorelines, and saltwater intrusion into freshwater lenses endangers coastal infrastructure, which is particularly crucial for those SIDS with few economic alternatives to tourism $[47,52]$. Concerning PICs, about $57 \%$ of their built infrastructure is located in risk-prone coastal areas [53].

The oceans and their sea life are other prominent tourism assets that are being affected. The world's oceans (especially the upper $2000 \mathrm{~m}$ ) in 2019 were the warmest in recorded human history [54]. The value of coral reef tourism was estimated to be 11.5 billion USD in 2010 [44,55]. Coral reefs are home to different organisms and endangered fish species. In 2010 , ocean acidification already threatened about $60 \%$ of the world's coral reefs [56]. Even if the global average temperature keeps within the $1.5^{\circ} \mathrm{C}$ limit, climate scientists believe that coral reefs will decline by a further $70-90 \%$; with a global temperature rise of $2{ }^{\circ} \mathrm{C}$, almost all coral reefs are expected to disappear [57] (p. 10). Eco- or biodiversity tourism has also been gaining more attention. Urban tourists with a keen interest towards nature usually select these destinations [58]. Here, dry spells increasingly lead to forest fires. The Mediterranean basin, for example, is being affected by increased temperatures, reduced rainfall and variations in seasonal patterns [59,60]; in California, climate change has been at least partially responsible for forest fires [61].

The consequences for tourism must also be considered in a socio-cultural and economic context, which may weigh even more in destinations where, for example, a large share of the population depends on tourism as a main source of income. As sea levels continue to rise at a high rate, especially affecting the Pacific region, decision-makers are beginning to discuss adaptive migration, i.e., the relocation of entire villages and island populations, as a response to sea-level rise and other natural hazards [47,62]. Other consequences are a shrinking productivity and harvest, changes in seasonal patterns, rise in prices for basic foodstuff and consumer goods, widespread poverty as a consequence of disastrous events, increasing spread of diseases due to higher temperatures, shortages of fresh water supply, wars over gaining access to limited resources, heat impacts on human health and well-being, and a high cost of adaptation and mitigation measures especially in coastal areas [63]. The Table 2 below provides some examples of the socio-economic impacts of climate change on tourism. 
Table 2. Selected examples of socio-economic impacts of climate change on tourism.

\begin{tabular}{|c|c|c|}
\hline Impacts & Consequences & Challenges \\
\hline \multicolumn{3}{|c|}{ Influence of temperature increase on supply and demand } \\
\hline \multirow{4}{*}{$\begin{array}{l}\text { Reduction of appropriate period of sun } \\
\text { exposure; Thermal stress; Increase in } \\
\text { incidence of skin cancer }\end{array}$} & $\begin{array}{l}\text { Redirection of demand to other potential } \\
\text { destinations. e.g., conservation units; }\end{array}$ & Promote low-carbon activity; \\
\hline & Adaptation of travel period; & $\begin{array}{l}\text { Offer destinations of nature all year } \\
\text { round; }\end{array}$ \\
\hline & $\begin{array}{l}\text { Fragmentation of holiday period with } \\
\text { reduction in stay; }\end{array}$ & $\begin{array}{l}\text { Promote actions and run campaigns on } \\
\text { sun protection }\end{array}$ \\
\hline & Poor quality of experience & \\
\hline \multicolumn{3}{|c|}{ Influence of extreme events on geographical space, demand, supply and agents } \\
\hline \multirow{10}{*}{$\begin{array}{l}\text { Destruction of tourism infrastructure; } \\
\text { Road blockades; Interruption of media } \\
\text { Services; Changes in hydrologic cycle }\end{array}$} & Real estate speculation; & $\begin{array}{c}\text { Foster new, more sustainable } \\
\text { destinations; }\end{array}$ \\
\hline & Contamination, spread of diseases; & $\begin{array}{c}\text { Promote actions and run campaigns } \\
\text { informing about protection and rational } \\
\text { use of resources; }\end{array}$ \\
\hline & Lack of drinking water; & $\begin{array}{c}\text { New investments, technologies and } \\
\text { marketing strategies; }\end{array}$ \\
\hline & High cost of recovery; & $\begin{array}{c}\text { Create plans, actions, develop strategies } \\
\text { to deal with consequences of extreme } \\
\text { events }\end{array}$ \\
\hline & $\begin{array}{l}\text { Low capacity for emergency care (rescue, } \\
\text { evacuation, medical services); }\end{array}$ & $\begin{array}{l}\text { Implement warning measures that } \\
\text { anticipate occurrences of extreme events }\end{array}$ \\
\hline & $\begin{array}{c}\text { Unavailability of emergency } \\
\text { accommodation, counseling and } \\
\text { assistance to victims; }\end{array}$ & $\begin{array}{l}\text { Implement measures to mitigate risk and } \\
\text { protect local inhabitants and tourists }\end{array}$ \\
\hline & Increase in price of trips; & \\
\hline & Insecurity; & \\
\hline & Poor quality of experience; & \\
\hline & Consumer distrust & \\
\hline \multicolumn{3}{|c|}{ Influence of sea-level rise on geographical space, supply and agents } \\
\hline \multirow{3}{*}{$\begin{array}{l}\text { Degradation of beaches; Bleaching of } \\
\text { corals; Coastal erosion; Destruction of } \\
\text { mangroves; Destruction of waterfront } \\
\text { infrastructure }\end{array}$} & Decrease in sand space for leisure & $\begin{array}{l}\text { Promote mitigation and adaptation } \\
\text { actions and initiatives; }\end{array}$ \\
\hline & Impacts on freshwater reserve; & $\begin{array}{c}\text { Plan and order use and territorial } \\
\text { occupation of the seaside; }\end{array}$ \\
\hline & High cost of waterfront restoration & $\begin{array}{c}\text { Implementation of coastal engineering } \\
\text { works }\end{array}$ \\
\hline
\end{tabular}

Source: [64] cited in [13] (p. 11).

Tourism stakeholders cannot neglect these impacts of climate change anymore, as they may render locations unattractive and result in declining tourist visits, potentially constraining the development path of popular destinations. Particularly valid for the Pacific region with its dispersed islands, climate change is just one of many serious challenges that they are confronted with [65] (p. 846). Many of them show a high vulnerability to climate impacts, but this vulnerability is unequally distributed, depending on the level of isolation, or remoteness, as well as adaptive capacity. The following Table 3 provides an overview of some of the already visible impacts of climate change on tourism attractions in the wider Pacific region, before exploring in more detail the cases of Tonga and the Solomon Islands. 
Table 3. Observed impacts of climate change on tourism in the wider Pacific region.

\begin{tabular}{|c|c|c|}
\hline Area & Impacts & Literature \\
\hline $\begin{array}{c}\text { Coral Triangle Initiative areas (Indonesia, Malaysia, } \\
\text { Papua New Guinea, Philippines, Solomon Islands and } \\
\text { Timor-Leste) }\end{array}$ & $\begin{array}{l}\text { Coral Reefs affected by impacts of climate change } \\
\text { Coral reefs attract majority tourists to visit the } \\
\text { CTI region } \\
\text { Sea-level rise major concern in Solomon } \\
\text { Islands communities } \\
\text { Coral Bleaching across the Pacific }\end{array}$ & $\begin{array}{l}{[66]} \\
{[67]} \\
{[49]} \\
{[68]}\end{array}$ \\
\hline South Western PICs & $\begin{array}{l}\text { Warming of sea grass linked with sea surface } \\
\text { temperature rise (SST) and ocean acidification. } \\
\text { Coral reef susceptibility at ecoregional scale with } \\
\text { increasing influence on conservation management. }\end{array}$ & $\begin{array}{l}{[69]} \\
{[70]}\end{array}$ \\
\hline PICs & $\begin{array}{l}\text { High-risk destination for disastrous events during } \\
\text { cyclone season. } \\
\text { Heavy rainfall events and flashfloods influence } \\
\text { travel choices. }\end{array}$ & $\begin{array}{l}{[71]} \\
{[72]}\end{array}$ \\
\hline Solomon Islands; Vanuatu; Fiji, Tonga; Samoa & $\begin{array}{l}\text { Negative impacts on mangrove and coastal } \\
\text { ecosystems' community livelihoods. }\end{array}$ & [73] \\
\hline
\end{tabular}

The following case studies of Tonga and the Solomon Islands offer interdisciplinary insights into concrete current challenges of climate change and the global pandemic for tourism and, consequently, sustainable national development, complemented by projected future impacts. The two assessed PICs are both characterized by the fact that their dependency on tourism has increased substantially, as evidenced by a long-term assessment of tourism receipts over 23 years: with 48.1 USD million in 2018, Tonga's tourism sector contributes today about a tenth of the island's GDP [74]. Even though the Solomon Islands are one of the least frequently visited islands worldwide, the steady growth in tourism receipts from USD 44 million in 2010 to USD 67 million in 2017 indicates the growing relevance of the tourism sector to Tonga [75] (p. 16).

\section{Vulnerability of Tonga's Tourism Sector to Climate Change}

Tonga, an upper middle-income country (gross national income (GNI)/capita: 404612,535 USD), comprises 170 islands with a total population of 105.365 [76]. Pristine beaches, coral atolls, active volcanoes, untouched rainforests, and rich cultural heritage form the basis of the offerings for tourists. Thanks to its favorable geographical position, tourism stands out as the second largest source of income following remittances and may be considered as the engine of economic development of the island [77]. Tourism-related services account for as much as $9.4 \%$ of Tonga's total GDP and approximately $22 \%$ of all international tourism revenues in Polynesia [74].

The Kingdom of Tonga is located in the seismically very active belt of the Pacific, the Pacific 'Ring of Fire', a zone of frequent earthquakes and volcanic eruptions, and Tonga regularly experiences other meteorological disasters. For example, there is an average of 1-2 tropical cyclones affecting the island during the wet season [78]. The risk of natural disasters constrains Tonga in seizing its full potential of tourism. The country's economic activity has been influenced by a range of natural disasters, with the main share of annual losses attributed to the impacts of cyclones (55\%), followed by storm surges (34\%), and earthquakes (10\%) [79]. The global COVID-19 outbreak adds further pressure due to lack of tourist arrivals, counteracting the previously observable steady increase from 26,000 in 1997 to 94,000 international tourist arrivals in 2019, which translated into 57,1 mio. in international tourism receipts (current USD). According to the Worldbank [80], data from the Pacific Community (SPC) show a double-digit decline due to COVID-19, underlining the seriousness of the impact of the pandemic on the national economy of Tonga: from January to June 2020 there was an average drop of $62.7 \%$ in tourist numbers, compared to 
the same period a year earlier, in which arrivals reduced by $20.8 \%$ between January and March and by 100\% in April to June 2020 as borders were closed [81].

Concerning the impact of disasters, about $18.1 \%$ of the population were affected by storms, translating into a $17.4 \%$ reduction of the GDP [82], illustrating the destructive connection of climate impacts and island development. As enlarged in Figure 1, the island groups of Tongatapu $\left(260 \mathrm{~km}^{2}\right)$ and 'Eua $\left(87 \mathrm{~km}^{2}\right)$ in the South, Vava'u $\left(121 \mathrm{~km}^{2}\right)$ in the North, Ha'apai $\left(109 \mathrm{~km}^{2}\right)$ in the middle, and Niuafo'ou and NiuaToputapu $\left(72 \mathrm{~km}^{2}\right)$ in the far north already suffer from climate impacts. SLR has damaged heritage sites and impacted infrastructure, ultimately affecting the tourism revenues and economic growth of these areas (see Table 5). With more than a $6 \mathrm{~mm}$ increase per year, the SLR near Tonga measured by satellite altimeters since 1993 is larger than the global average SLR of $3.2 \pm 0.4 \mathrm{~mm}$ per year. This rise is partly linked to a pattern related to climate variability from year to year and decade to decade as well as climate change [83].

The site Vava' $u$ is especially dependent on nature-based tourism activities (e.g., the swimming with whales industry) [84]. In recent years, climate impacts reduced the number of seasonal visitors, significantly reducing this source of tourism revenue [85]. Some sites, e.g., Tongatapu and Ha'apai, are already evidencing obvious economic losses due to climate impacts on the ecosystem, coastal landforms, and vegetation, with an estimated revenue loss of tens of millions of dollars [84,86]. Concerning coastal ecosystems, the Ha'apai and Vava'u sites face major consequences due to damages to the ecosystem health. Here, corals and some species of flora and fauna that live only in the coastal part make up a significant aspect of the appeal for tourists; hence ecosystem damage such as dying corals has a very detrimental impact on overall tourism growth and related development $[87,88]$. Drawing from identified literature on climate change impacts in Tonga, the following Table 4 highlights micro-level effects and their anticipated scope of socio-economic impacts. The existing literature is rather old, suggesting that further research is needed to update the often-outdated assessments and provide an empirically verified quantification of impacts.

Table 4. Observed impacts of climate change on tourism in Tonga.

\begin{tabular}{|c|c|c|c|}
\hline Site Level & Impacts & $\begin{array}{l}\text { Scope of Socio- } \\
\text { Economic } \\
\text { Impact }\end{array}$ & Literature \\
\hline Tongatapu, Vava'u, 'Eua, Ha'apai & $\begin{array}{l}\text { destruction of heritage sites } \\
\text { visitors \& operators affected } \\
\text { impact on infrastructure } \\
\text { impact on preservation and management } \\
\text { impact on cultural communities } \\
\text { village organization affected } \\
\text { impact on local government } \\
\text { economic loss/loss of revenue/financial loss }\end{array}$ & $\begin{array}{l}+++ \\
+++ \\
++ \\
- \\
++ \\
++ \\
+ \\
+++\end{array}$ & [89] \\
\hline Tongatapu, Vava'u, Ha'apai, 'Eua & $\begin{array}{l}\text { impacts on key land and marine-based natural areas for } \\
\text { tourism (e.g., beach loss resulting from sea-level rise and } \\
\text { inundation and damage to coastal tourist resorts) }\end{array}$ & +++ & [90] \\
\hline Tongatapu, Vava'u, Ha'apai, 'Eua & $\begin{array}{l}\text { impact on tourism business growth and development } \\
\text { number of seasonal visitors to Tonga reduced }\end{array}$ & $\begin{array}{l}+++ \\
+++\end{array}$ & [91] \\
\hline Tongatapu, Ha'apai & $\begin{array}{l}\text { devastated coastal landforms and vegetation } \\
\text { economic loss-more than } 18 \text { million TOP }\end{array}$ & $\begin{array}{c}+ \\
+ \\
++\end{array}$ & [92] \\
\hline Tongatapu, Ha'apai & $\begin{array}{l}\text { causing infrastructure damage to about } 90 \% \text { of } \\
\text { buildings (e.g., schools, churches, houses) }\end{array}$ & ++ & [93] \\
\hline Ha'apai, Vava'u & impacts on coral reef and coral reef health & - & [87] \\
\hline Vava'u & nature-based tourism affected & ++ & [94] \\
\hline Vava'u & indirectly affecting the swimming-with-whales industry & - & [84] \\
\hline \multirow[t]{2}{*}{ Vava'u } & displacement of tourists from Tonga & +++ & \multirow[t]{2}{*}{ [95] } \\
\hline & lost tourism revenues & +++ & \\
\hline
\end{tabular}

Source: Authors estimation based on literature source. Legend: +++ major impact; ++ large impact; + certain impact; - little impact. 
Based on the GHG concentration trajectories of the latest IPCC assessment report fo the Intergovernmental Panel on Climate Change (IPCC), climate predictions for Tonga indicate that current climate impacts may persist and even worsen: annual mean temperatures and extreme day temperatures are expected to increase further with a rise between $0.3-1.0{ }^{\circ} \mathrm{C}$ already observable in 2030 (see Table 5), more extreme rain events and slight increases in annual rainfall could be observed, sea-level rise continues, as does ocean acidification, which further increases the risk of coral bleaching. Drought is expected to slightly decrease. While wave heights and related shoreline impacts as well as tropical cyclones may decrease, the latter extreme events are expected to become more intense [18].

Table 5. Projected changes in the annual average surface air temperature for Tonga.

\begin{tabular}{ccccc}
\hline & $\mathbf{2 0 3 0}\left({ }^{\circ} \mathrm{C}\right)$ & $\mathbf{2 0 0 1 5}\left({ }^{\circ} \mathrm{C}\right)$ & $\mathbf{2 0 7 0}\left({ }^{\circ} \mathrm{C}\right)$ & $\mathbf{2 0 7 0}\left({ }^{\circ} \mathrm{C}\right)$ \\
\hline Very low emissions scenario & $0.3-0.9$ & $0.4-1.0$ & $0.3-1.0$ & $0.2-1.1$ \\
Low emissions scenario & $0.3-1.0$ & $0.6-1.4$ & $0.7-1.8$ & $0.8-2.1$ \\
Medium-emissions scenario & $0.3-0.8$ & $0.6-1.3$ & $0.8-1.8$ & $1.2-2.4$ \\
Very high emissions scenario & $0.4-1.0$ & $0.8-2.0$ & $1.4-2.9$ & $1.8-4.1$ \\
\hline
\end{tabular}

Source: [18]. The values represent $90 \%$ of the range of 24 models selected by the Pacific Climate Change Science and Adaptation Planning Program and are relative to the period 1986-2005.

The already observable impacts of climate change, combined with projections of possible futures, indicate that progressing climate change will continue to negatively impact the touristic attraction of Tonga, thus directly affecting and weakening the economic basis for economic growth, and influencing the path towards a sustainable national development.

Finally, Tonga appears to have been spared by the global pandemic to date, as evident by zero COVID cases reported to the WHO [96]. Yet the pandemic takes its toll, affecting at least $30 \%$ of the economy through severely impacting Tonga's tourism, retail, and construction sectors. However, entry to Tonga is also severely restricted, occasional repatriation flights are undertaken, but entry requires an official government permit, and all travelers have to go into quarantine for 14 days. In April 2020, though, the category 5 cyclone Harold hit Tonga hard, affecting about $27 \%$ of the population, with estimated damages and losses of more than $12 \%$ of GDP [97]. It also coincided with a king tide phenomenon, displacing 500 people [98].

\section{Vulnerability of the Solomon Islands' Tourism Sector to Climate Change}

The economy of the Solomon Islands, a lower-middle income country (GNI/capita: 1036-4045 USD), with a poverty rate of about $12.7 \%$, is largely based on services (around $40 \%$ of the GDP), with tourism having the largest share, along with agriculture (around $15 \%$ of GDP), and forestry (around 15\% GDP) [99,100].

Comprising of six main islands and over 900 smaller islands, the Solomon Islands have a total population of 681.808 [76]. The largest number of tourist visits is recorded in the period from June to October, although the favorable geographical and climatic position allows the tourist season to last all year round. Tourism has very favorable effects on the economic development of the island. Tourism appears to have the potential to become a driver of growth, but significant constraints and coordination challenges remain. These challenges currently impair tourism development, such as the provision of transport infrastructure and utilities, environmental management, or commercial access to land [101]. Despite these constraints, a steady increase from 5600 in 2004 to 28,900 in 2019 could be observed, which translated to USD 82 mio. in international tourism receipts, a share of almost $14 \%$ of total exports according to the Worldbank [100]. The latest data from the Pacific Community (SPC) indicate, however, a double-digit decline due to COVID-19, underlining the seriousness of the impact of the pandemic on the national economy of the Solomon Islands: between January to June 2020 tourist arrivals dropped by 68.8\%, compared to the same period a year earlier, in which there was a reduction in arrivals 
by $32.2 \%$ between January to March, and $100 \%$ in April to June 2020, as borders were closed [81].

Concerning the attractiveness of a destination for international travels, the main aspects of these islands that appeal to tourists are the untouched nature and richness of biodiversity along the coast and the way of life of the population, which is in harmony with the nature that surrounds them and away from some modern civilization achievements.

In addition to its exposure to slow-onset phenomena such as SLR, the Solomon Islands are a high-risk destination for extreme weather events. The cyclone season runs from June to November and is characterized by heavy rain and floods, deterring tourists during this period of the year. Natural resources that represent a significant part of the appeal for tourists are damaged as well. Finally, coastal erosion due to rising sea levels has already led to the destruction of mangroves that serve as a natural buffer against climate impacts, and if such a trend continues in the future, this may lead to their complete destruction. Heavy rains, storms, and floods do not only threaten coral reefs in the equatorial region, but the entire coastal ecosystem. In the year 2014, the Solomon Islands faced a natural disaster caused by floods along the river Matanikou. On that occasion, 49,000 people were left homeless. The consequences on the development of the tourism economy and the economic development in general were enormous, with damages estimated at around USD 107.7 million [99] (p. 1). This negatively impacted local tourism operators and consequently the entire country, in addition to the areas directly affected by the flood (Honiara, Guadalcanal, Isabel, Malaita, and Makira-Ulawa). Recovery of the ecosystems, infrastructure (e.g., roads, utilities), and tourism development was challenging. Moreover, rising ocean surface temperatures, seagrass warming, and ocean acidification already have significant implications and threaten the survival of ocean ecosystem biodiversity. If the necessary countermeasures are not taken, these negative effects will translate into a shrinking tourism industry in the island nation, as well as in the whole economy of the Pacific region (see Table 6).

Table 6. Observed impacts of climate change on tourism in the Solomon Islands.

\begin{tabular}{|c|c|c|c|}
\hline Site Level & Impacts & $\begin{array}{l}\text { Scope of } \\
\text { Socio-Economic } \\
\text { Impact }\end{array}$ & Literature \\
\hline Roviana, Western Province & $\begin{array}{l}\text { Impacts of tourism development on social and } \\
\text { ecological change in the Solomon Islands. } \\
\text { Tourism causing ecological changes to the } \\
\text { environment including climate change. }\end{array}$ & +++ & {$[102,103]$} \\
\hline Matanikou Riverside & $\begin{array}{l}\text { Flash flood of April } 2014 \text { along Matanikou } \\
\text { Riverside reduced national GDP by } \\
\text { USD } 107.7 \text { million. } \\
\text { Negative effects on local tourism operators }\end{array}$ & $\begin{array}{l}+++ \\
+++\end{array}$ & {$[104,105]$} \\
\hline Honiara & $\begin{array}{l}\text { Vector-control response in post-flood disaster } \\
\text { setting in the country } \\
\text { Incidents deter tourists from visiting the country }\end{array}$ & $\begin{array}{c}++ \\
+++\end{array}$ & {$[106,107]$} \\
\hline Various sites & $\begin{array}{l}\text { Mangroves in the country were severely affected } \\
\text { by climate change due to sea-level rise and } \\
\text { related coastal erosion. } \\
\text { This also has a link to tourist visits to the country, } \\
\text { as some travel to enjoy the biodiversity of the } \\
\text { coastal areas }\end{array}$ & $\begin{array}{l}- \\
++\end{array}$ & {$[108,109]$} \\
\hline Various sites & $\begin{array}{c}\text { Five vegetated reef islands vanished, six islands } \\
\text { with severe shoreline recession } \\
\text { Shoreline recession at two sites destroyed } \\
\text { villages, led to community relocations }\end{array}$ & $\begin{array}{l}+++ \\
+++\end{array}$ & [49] \\
\hline
\end{tabular}


Future climate projections are similar to those of Tonga, yet somewhat more pronounced, i.e., annual mean temperatures and extreme day temperatures are expected to increase further. With a rise between $0.4-1.0^{\circ} \mathrm{C}$ already observable in 2030 (see Table 7), sea-level rise continues, as does ocean acidification, which further increases the risk of coral bleaching. Drought is expected to slightly decrease. While wave heights and related shoreline impacts as well as tropical cyclones may decrease, the latter extreme events are expected to become more intense. Yet, annual rainfall projections remain unclear, with modelling results pointing to little change despite more extreme rain events (Pacific-Australia Climate Change Science and Adaptation Planning Program) [19].

Table 7. Projected changes in the annual average surface air temperature for the Solomon Islands.

\begin{tabular}{ccccc}
\hline & $\mathbf{2 0 3 0}\left({ }^{\circ} \mathrm{C}\right)$ & $\mathbf{2 0 0 1 5}\left({ }^{\circ} \mathrm{C}\right)$ & $\mathbf{2 0 7 0}\left({ }^{\circ} \mathrm{C}\right)$ & $\mathbf{2 0 7 0}\left({ }^{\circ} \mathrm{C}\right)$ \\
\hline Very low emissions scenario & $0.4-0.9$ & $0.6-1.2$ & $0.4-1.2$ & $0.4-1.2$ \\
Low emissions scenario & $0.4-1.0$ & $0.7-1.4$ & $0.9-1.8$ & $1.0-2.1$ \\
Medium-emissions scenario & $0.5-0.9$ & $0.7-1.4$ & $1.0-2.0$ & $1.3-2.6$ \\
Very high emissions scenario & $0.5-1.0$ & $1.0-1.9$ & $1.5-3.0$ & $2.0-4.0$ \\
\hline
\end{tabular}

Source: [19]. The values represent $90 \%$ of the range of 24 models selected by the Pacific Climate Change Science and Adaptation Planning Program and are relative to the period 1986-2005.

Similar to Tonga, the already observable impacts of climate change in the Solomon Islands, combined with projections of possible futures, indicate that progressing climate change will continue to negatively impact the touristic attraction of the Solomon Islands, thus directly affecting, i.e., weakening, the economic basis for economic growth and influencing the path towards a sustainable national development.

Regarding the global pandemic, the WHO dashboard reports a number of imported COVID 19 cases in in the Solomon Islands, with the first case being recorded in October 2020 [96]. The government initiated preparedness plans and declared a state of emergency early in 2020, then in the beginning of April 2020, category 5 storm Harold hit the islands, causing 27 deaths, widespread flooding, and damage to agricultural crops, i.e., affecting food security. This dual impact is projected to result in a GDP decline by about $5 \%$, job losses, and disrupted imports and supplies due to a lack of inbound flights [97]. This exemplifies how risks associated with facing multiple global phenomena is aggravated, resulting in dual challenges that have serious impacts and are difficult to overcome for SIDS such as the Solomon Islands.

\section{Discussion}

Global tourism plays an extremely ambivalent role like almost no other sector. On the one hand, it is one of the most important and fastest growing economic sectors in the world. One of every ten jobs is directly or indirectly dependent on tourism [22], and in many emerging and developing countries, particularly SIDS, with their attractive offer of sea, sun, and sand, it is the main source of foreign exchange earnings and the key driver of economic development [110]. On the other hand, the impact of tourism on the climate is particularly negative, with the sector playing a dual role in the sense of Eisenstein [111], as both perpetrator and victim. It has both a direct and indirect impact on tourism, varying from damages of tourist assets due to short-onset phenomena e.g., weather-related events, to slow-onset events like sea-level rise and rising temperatures resulting, for example, in a loss of biodiversity.

Climate change impacts are expected to have an increasing negative impact on the development of tourism in SIDS, where nature and biodiversity are an integral part of the appeal for tourists. In the Pacific region, coral reefs, low islands and coastal areas on high island regions are significantly threatened by climate change and related events [112]. In the equatorial Pacific, temperature increase is enhanced in a narrow band [113] (p. 1064).

Over the past decades, SLR appeared to not have resulted in massive land losses in atoll islands in the Pacific and Indian Ocean yet. However, some subregional variations in 
atoll behavior and within atoll variations in lagoon vs. ocean behavior may be attributed to climatic drivers [114]. Holdaway et al. [115], analyzing changes in land area on 221 atolls in the Indian and Pacific Ocean, found no scientific evidence of pervasive erosion under current levels of SLR. Instead, the total land area increased on some occasions, mainly through human (technical) interventions. However, according to the IPCC, despite a $1.5^{\circ} \mathrm{C}$ global warming, the sea level would continue to rise beyond 2100, resulting in increased saltwater intrusion affecting freshwater lenses, causing flooding, coastal erosion, and reduction of habitats for some endangered species $[112,116]$. Ocean warming will likely cause a continued decline in reef health, leading to a change in coral species composition, habitat loss and an up to $90 \%$ reduction of live coral cover by 2100 [112,117]. Climate change and a higher number of extreme weather events may also affect the food supply from agriculture and fisheries by reducing the food system's ability to recover, threatening subsistence agriculture, food security and, in the end, local livelihoods [118].

Every PIC is unique, so their complexity calls for island-specific assessments and localized, instead of generalized, solutions in response to global climate change $[17,119]$. The Pacific region might experience SLR of 40 to $80 \mathrm{~cm}$ by the end of this century, followed by a higher frequency and severity of inundation in coastal areas and intensified tropical cyclones [117]. For low-lying islands such as the Solomon Islands or Tonga, this may pose a significant risk, as, for example, long sandy beaches and the turquoise color of the sea are core elements of the tourism promise. The decreasing coastal sandy surface due to SLR and wave activity [46] can be used less and less as a beach and leads to a declining tourist interest in staying at these tourist resorts. Moreover, the destruction of heritage sites, another key element of the touristic attraction, may imply subsequent loss of local jobs as the business of heritage operators will decline. Some Solomon Islands have already disappeared, and shoreline recession has forced communities to relocate [46]. For Tonga, current SLR impacts could not be identified, but Nunn and Waddel [17], observing shoreline changes already in the last century, indicate that the tectonic uplift of most of Tonga's islands was not fast enough to offset the impacts of SLR.

The effect of climate impacts on SIDS infrastructure is significant [120,121]. Coastal defense structures as a potential countermeasure against shoreline recession are often linked to large investments; ecosystem-based (EBA) solutions appear to resemble a more appropriate measure in PICs. For Micronesia, Nunn et al. [17] assessed such shoreline changes induced by rapid SLR and found that mangrove forests were capable of absorbing wave energy and even the effects of SLR. Indeed, mangrove planting (the most common EBA measure) appears to be the preferred SLR response, as evidenced in a study of 30 SIDS [46,122]. Moreover, community-based adaption (CBA) is crucial for the Pacific region, and recent CBA research suggests that locally-led, community-driven action that is facilitated and resourced by donors and implementers may represent the most sustainable way to achieve local objectives [123].

The immediate primary effects of extreme weather events, i.e., injury and death as a result of flooding and cyclones, first and foremost put local populations at risk, but these events certainly also impact tourist locations. Additionally, disrupted health care systems, compromised supplies of freshwater and safe food, and possibly unhygienic makeshift shelters, can slow down recovery. In small island nations, where land tenure and rights are a source of conflict, climate change induced migration could cause social and economic unrest [124]. There is also growing concern that climate change induced relocation may increase in the future, leading to ontological insecurities. For the Pacific region, further research is needed, as understanding the local factors that lead to an increase in the susceptibility of PICs to coastal erosion appears to be key in guiding adaptation responses for remote Pacific communities [48]. This is particularly relevant for the continuancy of the sun, sea, and sand tourism in the region.

It is also largely undisputed in the scientific community that the implications of climate change, including increasing $\mathrm{CO}_{2}$ emissions, may lead to a significant redistribution of tourism demand between destinations in the medium to long term. This will be accompa- 
nied by the emergence of winning and losing regions. PICs in particular, but also a number of destinations in the Mediterranean region, may be disadvantaged due to progressing sea-level rise and a significant increase in extreme weather events, while regions with a more temperate climate, such as northern and central Europe, are expected to benefit from rising touristic demand [125-128].

Even though Tonga and the Solomon Islands do not qualify as major tourism hubs like, for example, Fiji, the islands are increasingly dependent on the sector for their national development due to a lack of sustainable alternatives. In addition, low-lying reef islands, such as in the Solomon Islands or Tonga, can offer valuable lessons on future impacts, especially of global sea-level rise, and to date there appears to be only limited research on such islands in this western Pacific region. Due to the increasing adverse impacts of climate change on these islands, more research needs to be undertaken to offer pathways for a sustainable development of these vulnerable nations, as well as the surrounding region. Despite existing regional climate projections, downscaling these remains a challenge, therefore distinctive climate impacts on island level may be anticipated, but remain uncertain in scope. Until then, uncertainties will remain and force the island's decision-makers to adopt precautionary measures to reduce inherent vulnerabilities and strengthen resilience of their populations.

Finally, climate change and COVID-19 may be considered as systemically coupled, complex and contested problems. Schipper et al. [129] (p. 5) point out that "socioenvironmental shocks and stresses, like COVID-19 and climate change, are at once the drivers and outcomes of predominant development pathways". This points towards an essential need to alter fundamental attributes of development, i.e., trigger disruptive transformation processes, not only concerning climate change adaptation, but also sectoral transformation of tourism, all of which may be utilized to accelerate deployment of sustainable technologies and economies for a climate resilient development path [130,131].

The following table summarizes the main research directions addressed in this paper, highlights some key research gaps and gives some recommendations for future research (see Table 8).

Table 8. Main research directions addressed, research gaps identified, and recommendations for future research.

\begin{tabular}{ccc}
\hline Tourism development & Main Research Gaps & Future Research Needs \\
\hline $\begin{array}{c}\text { Development trajectories incorporating } \\
\text { uncertainties due to and interrelations with } \\
\text { global phenomena like pandemics; } \\
\text { geographical research bias; equity dimension; } \\
\text { socio-cultural and economic contexts }\end{array}$ & $\begin{array}{c}\text { Sustainable growth models fostering } \\
\text { international tourism development; } \\
\text { improved regional and local projections; } \\
\text { sustainable tourism development and equity }\end{array}$ \\
\hline Climate impacts on tourism sector & $\begin{array}{c}\text { Empirical assessments of tourism service } \\
\text { chain; true social cost of carbon }\end{array}$ & $\begin{array}{c}\mathrm{CO}_{2} \text { assessments of tourism sub-segments; } \\
\text { improved social cost of carbon accounting }\end{array}$ \\
\hline $\begin{array}{c}\text { Uncertainties in climate projections; lack of } \\
\text { empirical data/scientific assessments of local } \\
\text { impacts; thresholds of local adaptation } \\
\text { potential; economic analyses of the monetary } \\
\text { value of the damages of climate change on } \\
\text { tourism; social costs of carbon }\end{array}$ & $\begin{array}{c}\text { Improved uncertainty assessments; impact } \\
\text { assessments with focus on developing } \\
\text { countries; transformative adaptation } \\
\text { potential; more and improved economic } \\
\text { analyses of benefits and cost of tourism, } \\
\text { especially for developing countries }\end{array}$ \\
\hline
\end{tabular}

\section{Conclusions}

As this paper has shown, tourism plays an ambivalent role for touristic destinations, not just in Pacific SIDS; a decoupling between economic growth and environmental pollution, at least in the context of the tourism industry, has not yet been proven. This may have severe implications for the global tourism industry, and, consequently, the sustainable development of Pacific PICs such as Tonga or the Solomon Islands: 
- Tourism-related $\mathrm{CO}_{2}$ emissions will continue to drive anthropogenic climate change, from which SIDS, particularly those that are vulnerable, will suffer, and island nations remain in a quandary as to how to alleviate the harmful environmental effects of tourism-related GHG emissions whilst maintaining an attractive tourist destination.

- Tourism represents an indispensable pillar of national income in Pacific SIDS, securing local livelihoods, yet the socio-economic effects of the global pandemic underscore the fatal dependency on the sector whose abrupt decline severely endangers national development and well-being.

- Climate impacts and related changes in tourism demand may lead to a shrinking tourism sector, with severe implications for sustainable national development and well-being, as revealed by the case studies of Tonga and the Solomon Islands that provide evidence of reduced touristic attractiveness of these island destinations.

- The global pandemic may serve to push the tourism sector towards more sustainability in terms of redesigning offers and reducing its carbon footprint, but a firm commitment of the sector is yet to be seen due to lacking international mitigation measures.

- Benefits from reductions in $\mathrm{CO}_{2}$ emissions from tourism need to be weighed against the substantial economic losses caused by lack of revenue from tourism, which thousands of people depend on.

This paper sheds a light on what drives vulnerability of the tourism sector in Pacific SIDS like Tonga or the Solomon Islands in the light of substantial economic, ecologic, and social vulnerability induced by societal challenges, with special attention to climate change and the global pandemic. There is a paucity of recent research on observed climate change impacts on these islands which is illustrated by scarce literature on observed impacts. This suggests an urgent need for more research in these islands as well as in the overall Pacific region to gain current insights, enable detailed projections to be made on how global changes will impact these vulnerable islands in future, and develop flexible adaptation options that allow an improved consideration of remaining uncertainties.

It is obvious that the current COVID-19 pandemic has led to significant reductions in international travel and in the numbers of tourists, placing many millions of livelihoods at risk, including in developing countries [132]. Yet travel and tourism could also become key sectors that support the recovery of the global economy by revitalizing employment and driving visitors back to distant destinations [20]. In this respect, it is important that clean technologies are more widely deployed by SIDS (e.g., increased use of renewable energy in tourism facilities) since they can not only help to promote local energy security and reduce operational costs, but may also lead to reductions in the carbon footprint of the tourism industry.

Strengthening the maritime and air transport infrastructure on island nations, so as to allow it to uphold trade and tourism development, would imply substantial investments in sustainable technology, which brings about the advantage of making infrastructure less vulnerable to damages from extreme events. Combining engineering solutions to increase climate resilience (e.g., coastal protection against waves) with less capital-intensive approaches (e.g., ecosystem-based adaptation such as reconstruction of mangroves) linked with community-based adaptation action can increase resilience to climate impacts, empower communities, and secure local livelihoods.

To ensure this can happen, the strategies and measures chosen need to be sustainable not just for the sector in question; SIDS decision-makers will need to pay attention to policy coherence so as to ensure overall societal well-being and to leave no-one behind.

Author Contributions: Conceptualization, W.L.F. and F.W.; methodology, all authors; formal analysis, N.S., D.R., I.B.M. and F.W.; data curation, all authors; writing-original draft preparation, all authors; writing-review and editing, F.W., all authors; visualization, M.K., P.H.H., N.S., C.L. and F.W. All authors have read and agreed to the published version of the manuscript.

Funding: This research received no external funding.

Institutional Review Board Statement: Not applicable. 
Informed Consent Statement: Not applicable.

Data Availability Statement: Not applicable.

Acknowledgments: The authors wish to thank the anonymous reviewers whose comments helped to improve the paper.

Conflicts of Interest: The authors declare no conflict of interest.

\section{References}

1. Becken, S. A review of tourism and climate change as an evolving knowledge domain. Tour. Manag. Perspect. 2013, 6, 53-62. [CrossRef]

2. Hall, C.M.; Higham, J. (Eds.) Tourism, Recreation and Climate Change; Channel View Publications: Clevedon, UK, 2005.

3. Becken, S.; Hay, J.E. Risk and Opportunities. In Tourism and Climate Change; Channel View Publications: Clevedon, UK, 2007.

4. UNWTO; UNEP. Responding to Global Challenges. In Climate Change and Tourism; UNWTO Publishing: Madrid, Spain, 2008.

5. Jones, A.; Phillips, M. (Eds.) Recognizing Problems, Managing Solutions and Future Expectations. In Global Climate Change and Coastal Tourism; CABI: Wallingford, UK, 2018.

6. Gössling, S. Carbon management in tourism mitigation. In The Impacts of Climate Change; Routledge: Abingdon, UK, 2011.

7. Scott, D.; Hall, C.M.; Stefan, G. Impacts, adaptation and mitigation. In Tourism and Climate Change; Routledge: London, UK, 2012.

8. OECD; UNEP. Climate change and tourism. In Policy in OECD Countries; OECD Publishing: Paris, France, 2008.

9. Becken, S.; Hay, J. From policy to practice. In Climate Change and Tourism; Routledge: London, UK, 2012.

10. Reddy, M.V.; Wilke, K. (Eds.) Tourism, Climate Change and Sustainability; Routledge: Abingdon, UK, 2013.

11. UNCTAD. The Oceans Economy: Opportunities and Challenges for Small Island Developing States. 2014. Available online: https:/ / www.sdgfund.org/oceans-economy-opportunities-and-challenges-small-island-developing-states (accessed on 3 November 2020).

12. Fang, Y.; Yin, J.; Wu, B. Climate change and tourism: A scientometric analysis using CiteSpace. J. Sustain. Tour. 2018, 26, 108-126. [CrossRef]

13. Grimm, I.J.; Alcântara, L.C.S.; Sampaio, C.A.C. O turismo no cenário das mudanças climáticas: Impactos, possibilidades e desafios. Rev. Braz. Pesqui. Tur. 2018, 12, 1-22. [CrossRef]

14. IPCC. Climate Change 2014: Impacts, Adaptation, and Vulnerability. Part A: Global and Sectoral Aspects. In Contribution of Working Group II to the Fifth Assessment Report of the Intergovernmental Panel on Climate Change; Field, C.B., Barros, V.R., Dokken, D.J., Mach, K.J., Mastrandrea, M.D., Bilir, T.E., Chatterjee, M., Ebi, K.L., Estrada, Y.O., Genova, R.C., et al., Eds.; Cambridge University Press: Cambridge, UK; New York, NY, USA, 2014; 1132p.

15. Connelly, A.; Carter, J.; Handley, J.; Hincks, S. Enhancing the Practical Utility of Risk Assessments in Climate Change Adaptation. Sustainability 2018, 10, 1399. [CrossRef]

16. Stocker, T.F.; Qin, D.; Plattner, G.-K.; Tignor, M.M.B.; Allen, S.K.; Boschung, J.; Nauels, A.; Xia, Y.; Bex, V.; Midgley, P.M. Sea Level Change. In Climate Change 2013: The Physical Science Basis. Contribution of Working Group I to the Fifth Assessment Report of the Intergovernmental Panel on Climate Change; Cambridge University Press: Cambridge, UK; New York, NY, USA.

17. Nunn, P.; Waddel, E. Implication of Climate Change and Sea-Level Rise for the Kingdom of Tonga. South Pacific Regional Environment Programme. Apia, Samoa. 1992. Available online: https://www.sprep.org/att/IRC/eCOPIES/Countries/Tonga/ 24.pdf (accessed on 26 September 2020).

18. PACCSAP. Current and Future Climate of Tonga. Pacific-Australia Climate Change Science and Adaptation Planning Program. 2015. Available online: https://www.pacificclimatechangescience.org/wp-content/uploads/2013/06/10_PACCSAP-Tonga11pp_WEB.pdf (accessed on 13 February 2021).

19. PACCSAP. Current and Future Climate of the Solomon Islands. Pacific-Australia Climate Change Science and Adaptation Planning Program. 2015. Available online: https://www.pacificclimatechangescience.org/wp-content/uploads/2013/06/13 _PACCSAP-Solomon-Islands-11pp_WEB.pdf (accessed on 13 February 2021).

20. WTTC. Travel and Tourism: Global Economic impact and Trends 2020. World Travel and Tourism Council. 2020. Available online: https:/ / www.wttc.org/economic-impact/ (accessed on 15 August 2020).

21. World Tourism Organization. UNWTO Tourism Highlights 2019 Edition; UNWTO: Madrid, Spain, 2019.

22. WTTC. Travel and Tourism: Economic impact 2019-World. World Travel and Tourism Council. 2019. Available online: https:/ / www.wttc.org/economic-impact/ (accessed on 2 December 2019).

23. UNWTO. COVID-19 and Tourism 2020: A Year in Review. 2021. Available online: https://webunwto.s3.eu-west-1.amazonaws. com/s3fs-public/2020-12/2020_Year_in_Review_0.pdf (accessed on 9 February 2021).

24. McElroy, J.L. A note on the significance of geographic location in island studies. Isl. Stud. J. 2014, 9, $363-366$.

25. UNWTO. Making Tourism Work for Small Island Developing States; World Tourism Organization: Geneva, Switzerland, 2004.

26. UNWTO. Tourism in SIDS: The Challenge of Sustaining Livelihoods in Times of COVID-19. UNWTO Briefing Note-Tourism and COVID-19, ISSUE 2. June 2020. Available online: https:/ /www.e-unwto.org/doi/epdf/10.18111/9789284421916 (accessed on 9 September 2020).

27. ADB. Tourism as Driver of Growth in the Pacific; Issues in Pacific Development, No. 2; Asian Development Bank: Manial, Philippines, June 2018. 
28. Cheer, J.M.; Pratt, S.; Tolkach, D.; Bailey, A.; Taumoepeau, S.; Movono, A. Tourism in Pacific island countries: A status quo round-up. Asia Pac. Policy Stud. 2018, 5, 442-461. [CrossRef]

29. Harrison, D.; Pratt, S. Tourism in Pacific island countries: Current issues and future challenges. In Tourism in Pacific Islands: Current Issues and Future Challenges; Pratt, S., Harrison, D., Eds.; Routledge: New York, NY, USA, 2015; pp. 3-21.

30. Filho, W.L.; Lütz, J.M.; Sattler, D.N.; Nunn, P.D. Coronavirus: COVID-19 Transmission in Pacific Small Island Developing States. Int. J. Environ. Res. Public Health 2020, 17, 5409. [CrossRef] [PubMed]

31. Hambleton, I.R.; Jeyaseelan, S.M.; Murphy, M.M. COVID-19 in the Caribbean small island developing states: Lessons learnt from extreme weather events. Lancet Glob. Health 2020, 8, e1114-e1115. [CrossRef]

32. Gössling, S.; Scott, D.; Hall, C.M. Pandemics, tourism and global change: A rapid assessment of COVID-19. J. Sustain. Tour. 2020, 29, 1-20. [CrossRef]

33. UNCTAD. Impact of COVID-19 on Tourism in Small Island Developing States. 2020. Available online: https://unctad.org/news/ impact-covid-19-tourism-small-island-developing-states (accessed on 14 November 2020).

34. Lenzen, M.; Sun, Y.-Y.; Faturay, F.; Ting, Y.-P.; Geschke, A.; Malik, A. The carbon footprint of global tourism. Nat. Clim. Chang. 2018, 8, 522-528. [CrossRef]

35. Global Sustainable Tourism Dashboard. 2019. Available online: https://www.tourismdashboard.org/ (accessed on 26 September 2020).

36. Friedl, H.A. Tourismusethik: Theorie und Praxis des umwelt- und Sozialverträglichen Fernreisens; Profil: München, Germany, 2002.

37. Gross, S.; Grimm, B. Sustainable mode of transport choices at the destination-Public transport at German destinations. Tour. Rev. 2018, 73, 401-420. [CrossRef]

38. Scott, D.; Peeters, P.; Gössling, S. Can tourism deliver its "aspirational” greenhouse gas emission reduction targets? J. Sustain. Tour. 2010, 18, 393-408. [CrossRef]

39. Dorta Antequera, P.; Díaz Pacheco, J.; López Díez, A.; Bethencourt Herrera, C. Tourism, Transport and Climate Change: The Carbon Footprint of International Air Traffic on Islands. Sustainability 2021, 13, 1795. [CrossRef]

40. Gössling, S.; Peeters, P. Assessing tourism's global environmental impact 1900-2050. J. Sustain. Tour. 2015, 23, 639-659. [CrossRef]

41. Le Quéré, C.; Jackson, R.B.; Jones, M.W.; Smith, A.J.P.; Abernethy, S.; Andrew, R.M.; De-Gol, A.J.; Willis, D.R.; Shan, Y.; Canadell, J.G.; et al. Temporary reduction in daily global $\mathrm{CO}_{2}$ emissions during the COVID-19 forced confinement. Nat. Clim. Chang. 2020, 10, 647-653. [CrossRef]

42. Scott, D.; Lemieux, C. Weather and Climate Information for Tourism. Procedia Environ. Sci. 2010, 1, 146-183. [CrossRef]

43. Hamilton, J.M.; Tol, R.S.J. The impact of climate change on tourism in Germany, the UK and Ireland: A simulation study. Reg. Environ. Chang. 2007, 7, 161-172. [CrossRef]

44. Siddiqui, S.; Imran, M. Impact of Climate Change on Tourism; IGI Global: Pennsylvania, PA, USA, 2019 ; pp. 68-83.

45. Yazdanpanah, H.; Barghi, H.; Esmaili, A. Effect of climate change impact on tourism: A study on climate comfort of Zayandehroud River route from 2014 to 2039. Tour. Manag. Perspect. 2016, 17, 82-89. [CrossRef]

46. Rosselló-Nadal, J. How to evaluate the effects of climate change on tourism. Tour. Manag. 2014, 42, 334-340. [CrossRef]

47. Oppenheimer, M.; Glavovic, B.C.; Hinkel, J.; van de Wal, R.; Magnan, A.K.; Abd-Elgawad, A.; Cai, R.; Cifuentes-Jara, M.D.; Robert, M.; Ghosh, T.; et al. Chapter 4: Sea Level Rise and Implications for Low-Lying Islands, Coasts and Communities. In IPCC Special Report on the Ocean and Cryosphere in a Changing Climate; Pörtner, H.-O., Roberts, D.C., Masson-Delmotte, V., Zhai, P., Tignor, M., Poloczanska, E., Mintenbeck, K., Alegría, A., Nicolai, M., Okem, A., et al., Eds.; 2019; Available online: https://www.ipcc.ch/site/assets/uploads/sites/3/2019/12/SROCC_FullReport_FINAL.pdf (accessed on 1 April 2021).

48. NOAA. Climate Change: Global Sea Level. Rebecca Lindsey. 14 August 2020. Available online: https://www.climate.gov/newsfeatures/understanding-climate/climate-change-global-sea-level (accessed on 12 September 2020).

49. Albert, S.; Leon, J.X.; Grinham, A.R.; A Church, J.; Gibbes, B.R.; Woodroffe, C.D. Interactions between sea-level rise and wave exposure on reef island dynamics in the Solomon Islands. Environ. Res. Lett. 2016, 11, 054011. [CrossRef]

50. Klein, A. Eight Low-Lying Pacific Islands Swallowed Whole by Rising Seas. New Scientist. Earth. 7 September 2017. Available online: https:/ / www.newscientist.com/article/2146594-eight-low-lying-pacific-islands-swallowed-whole-by-rising-seas / \#ixzz6XoteQAMC (accessed on 12 September 2020).

51. Nunn, P.D.; Kohler, A.; Kumar, R. Identifying and assessing evidence for recent shoreline change attributable to uncommonly rapid sea-level rise in Pohnpei, Federated States of Micronesia, Northwest Pacific Ocean. J. Coast. Conserv. 2017, 21, 719-730. [CrossRef]

52. Belle, N.; Bramwell, B. Climate Change and Small Island Tourism: Policy Maker and Industry Perspectives in Barbados. J. Travel Res. 2005, 44, 32-41. [CrossRef]

53. Kumar, L.; Taylor, S. Exposure of coastal built assets in the South Pacific to climate risks. Nat. Clim. Chang. 2015, 5, 992-996. [CrossRef]

54. Cheng, L.; Abraham, J.; Zhu, J.; Trenberth, K.E.; Fasullo, J.; Boyer, T.; Locarnini, R.; Zhang, B.; Yu, F.; Wan, L.; et al. Record-Setting Ocean Warmth Continued in 2019. Adv. Atmos. Sci. 2020, 37, 137-142. [CrossRef]

55. Laffoley, E.D.; Baxter, J.M.; Turley, C.; Lagos, N.A. An Introduction to Ocean Acidification. 2017. Available online: https: / / www.iaea.org/sites/default/files/18/06/oa-introduction-2017.pdf (accessed on 24 November 2019).

56. IAEA Ocean Acidification International Coordination Centre (OA-ICC). 2015. Available online: https://www.iaea.org/services/ oa-icc (accessed on 28 September 2020). 
57. Masson-Delmotte, V.; Zhai, P.; Portner, H.-O.; Roberts, D.; Skea, J.; Shukla, P.R.; Pirani, A.; Moufouma-Okia, W.; Pean, C.; Pidcock, R.; et al. Impacts of $1.5^{\circ} \mathrm{C}$ global warming on natural and human systems. In Global Warming of $1.5^{\circ} \mathrm{C}$; An IPCC Special Report on the impacts of global warming of $1.5^{\circ} \mathrm{C}$ above pre-industrial levels and related global greenhouse gas emission pathways, in the context of strengthening the global response to the threat of climate change, sustainable development, and efforts to eradicate poverty; Intergovernmental Panel on Climate Change: Geneva, Switzerland, 2018; pp. 175-311.

58. Dudek, T. Recreational potential as an indicator of accessibility control in protected mountain forest areas. J. Mt. Sci. 2017, 14, 1419-1427. [CrossRef]

59. Pausas, J.G.; Fernández-Muñoz, S. Fire regime changes in the Western Mediterranean Basin: From fuel-limited to drought-driven fire regime. Clim. Chang. 2011, 110, 215-226. [CrossRef]

60. Cramer, W.; Guiot, J.; Fader, M.; Garrabou, J.; Gattuso, J.-P.; Iglesias, A.; Lange, M.A.; Lionello, P.; Llasat, M.C.; Paz, S.; et al. Climate change and interconnected risks to sustainable development in the Mediterranean. Nat. Clim. Chang. 2018, 8, 972-980. [CrossRef]

61. Mulkern, A. Fast-Moving California Wildfires Boosted by Climate Change. Scientific American. 2020. Available online: https:/ / www.scientificamerican.com/article/fast-moving-california-wildfires-boosted-by-climate-change/ (accessed on 27 September 2020).

62. Burson, B.; Bedford, R. Clusters and Hubs: Toward a Regional Architecture for Voluntary Adaptive Migration in the Pacific; Technical Report; The Nansen Initiative: Geneva, Switzerland, 2013; pp. 1-56.

63. Iberdrola. The Impact of Climate Change. How Is Climate Change Affecting the Economy and Society? 2020. Available online: https:/ / www.iberdrola.com/environment/impacts-of-climate-change (accessed on 26 September 2020).

64. Grimm, I.J. Mudanças Climáticas e o Tu-rismo: Estratégias de Adaptação e Mitigação. Ph.D. Thesis, Universidade Federal do Paraná, Curitiba, Brazil, 2016; 250p.

65. Nurse, L.A.; Sem, G.; Hay, J.E.; Suarez, A.G.; Wong, P.P.; Briguglio, L.; Ragoonaden, S. Small island states. In Climate Change 2001: Impacts, Adaptation and Vulnerability; Contribution of Working Group II to the Third Assessment of theIntergovernmental Panel on Climate Change; McCarthy, J.J., Canziani, O.F., Leary, N.A., Dokken, D.J., White, K.S., Eds.; Cambridge University Press: Cambridge, UK; New York, NY, USA, 2001; pp. 843-876.

66. McLeod, E.; Hinkel, J.; Vafeidis, A.T.; Nicholls, R.J.; Harvey, N.; Salm, R. Sea-level rise vulnerability in the countries of the Coral Triangle. Sustain. Sci. 2010, 5, 207-222. [CrossRef]

67. Wilkinson, C.R. Global change and coral reefs: Impacts on reefs, economies and human cultures. Glob. Chang. Biol. 1996, 2, 547-558. [CrossRef]

68. Sulu, R.; Cumming, R.; Wantiez, L.; Kumar, L.; Mulipola, A.; Lober, M.; Pakoa, K. Status of coral reefs in the southwest Pacific to 2002: Fiji, Nauru, New Caledonia, Samoa, Solomon Islands, Tuvalu and Vanuatu. In Status of Coral Reefs of the World; GCRMN/Australian Institute of Marine Science: Queensland, Australia, 2002; pp. 181-201.

69. McLeod, E.; Moffitt, R.; Timmermann, A.; Salm, R.; Menviel, L.; Palmer, M.J.; Selig, E.R.; Casey, K.S.; Bruno, J.F. Warming Seas in the Coral Triangle: Coral Reef Vulnerability and Management Implications. Coast. Manag. 2010, 38, 518-539. [CrossRef]

70. Lovell, E.; Sykes, H.; Deiye, M.; Wantiez, L.; Garrigue, C.; Virly, S.; Samuelu, J.; Solofa, A.; Poulasi, T.; Pakoa, K.; et al. Status of Coral Reefs in the South West Pacific: Fiji, Nauru, New Caledonia, Samoa, Solomon Islands, Tuvalu and Vanuatu. In Status of Coral Reefs of the World; GCRMN/Australian Institute of Marine Science: Queensland, Australia, 2004; pp. $337-362$.

71. Wilks, J. Chapter 17. Destination Risk Management in Oceania. Oceania 2005, 17, 335-352. [CrossRef]

72. Lal, P.N. Climate Change Adaptation in the Pacific: Making Informed Choices; A report prepared for the Australian Department of Climate Change and Energy Efficiency (DCCEE); IUCN: Suva, Fiji, 2011.

73. IUCN. Impacts of Projected Climate Change on Mangrove and Coastal Ecosystems and Community Livelihoods in Solomon Islands, Vanuatu Fiji, Tonga, Samoa; IUCN: Suva, Fiji, 2013.

74. World Data Info. Tourism in Tonga. 2020. Available online: https://www.worlddata.info/oceania/tonga/tourism.php (accessed on 17 April 2020).

75. UNWTO. Tourism Highlights 2018 Report. 2018. Available online: https://www.e-unwto.org/doi/pdf/10.18111/9789284419876 75 (accessed on 16 April 2020).

76. World Population Review. 2020. Available online: https://worldpopulationreview.com/ (accessed on 14 March 2020).

77. CIA World Factbook. Tonga. 2020. Available online: https://www.cia.gov/the-world-factbook/countries/tonga/ (accessed on 20 February 2021).

78. TMS. Tonga Meteorological Service. 2021. Available online: http://www.met.gov.to/index_files/climate_summary_tonga.pdf (accessed on 20 February 2021).

79. PreventionWeb. Disaster and Risk Profile. Basic Country Statistics and Indicators. 2014. Available online: https://www. preventionweb.net/countries/ton/data/ (accessed on 2 March 2021).

80. Worldbank. International Tourism, Receipts (Current US\$)—Tonga. 2021. Available online: https://data.worldbank.org/ indicator/ST.INT.RCPT.CD?locations=TO (accessed on 20 February 2021).

81. SPC. Visitor Arrival Numbers Slump in the Pacific Island Countries and Territories. Pacific Community. 2020. Available online: https:/ / www.spc.int/updates/blog/blog/2020/12/visitor-arrival-numbers-slump-in-the-pacific-island-countries-and (accessed on 20 February 2021). 
82. Nurse, L.A.; McLean, R.F.; Agard, J.; Briguglio, L.P.; Duvat-Magnan, N. Pelesikoti, E. Tompkins, and A. Webb. Small islands. In Climate Change 2014: Impacts, Adaptation, and Vulnerability; Part B: Regional Aspects.Contribution of Working Group II to the Fifth Assessment Report of the Intergovernmental Panel on Climate, Change; Barros, V.R., Field, C.B., Dokken, D.J., Mastrandrea, M.D., Mach, K.J., Eds.; Cambridge University Press: Cambridge, UK; New York, NY, USA, 2014; pp. 1613-1654.

83. Mimura, N.; Pelesikoti, N. Vulnerability of Tonga to future sea-level rise. J. Coast Res. 1997, 24, 117-132.

84. Fiori, L.; Martinez, E.; Orams, M.B.; Bollard, B. Effects of whale-based tourism in Vava'u, Kingdom of Tonga: Behavioural responses of humpback whales to vessel and swimming tourism activities. PLoS ONE 2019, 14, e0219364. [CrossRef]

85. Daniel, J.; Banerji, A.; Neves, R.; Prihardini, D.; Sandoz, C.; Zdzienicka, A.; Blackman, A.; Esler, S.; Palu, N.; Piatkov, V.; et al. Tonga Climate Change Policy Assessment; IMF Country Report No.20/212; International Monetary Fund: Washington, DC, USA, 2020.

86. Ram-Bidesi, V.; Lal, P.N.; Conner, N. Economics of Coastal Zone Management in the Pacific. IUCN, USP, SPREP, SPC. 2021. Available online: https://portals.iucn.org/library/sites/library/files/documents/2011-119.pdf (accessed on 1 September 2020).

87. Mayfield, A.B.; Chen, C.-S.; Dempsey, A.C. Biomarker profiling in reef corals of Tonga's Ha'apai and Vava'u archipelagos. PLoS ONE 2017, 12, e0185857. [CrossRef] [PubMed]

88. Lovell, E.; Palaki, A. National Coral Reef Status Report Tonga. Coral Reefs in the Pacifie: Status and Monitoring; Resources and Management IRD. 2002. Available online: https://horizon.documentation.ird.fr/exl-doc/pleins_textes/divers14-11/010032224 .pdf (accessed on 1 September 2020).

89. Institute for Business Research. Tongan Heritage Tourism Scoping Study; The University of Waikato: Hamilton, New Zealand, 2012.

90. Ministry of Finance and National Planning. Climate Financing and Risk Governance Assessment (CFRGA) Report; Government of Tonga: Nukuálofa, Tonga, 2016.

91. TRIP Consultants. Tonga Tourism Sector Roadmap 2014-2018; Tonga Tourism Sector, Government of Tonga: Nukuálofa, Tonga, 2013.

92. Woodroffe, C.D. The impact of Cyclone Isaac on the Coast of Tonga. Pac. Sci. 1983, 37, 181-210.

93. Reardon, G.; Oliver, J. The impact of cyclone Isaac on buildings on Tonga. J. Wind. Eng. Ind. Aerodyn. 1983, 14, 67-78. [CrossRef]

94. Van Der Veeken, S.; Calgaro, E.; Klint, L.M.; Law, A.; Jiang, M.; De Lacy, T.; Dominey-Howes, D. Tourism destinations' vulnerability to climate change: Nature-based tourism in Vava'u, the Kingdom of Tonga. Tour. Hosp. Res. 2016, 16, 50-71. [CrossRef]

95. Orams, M.B. Humpback Whales in Tonga: An Economic Resource for Tourism. Coast. Manag. 2002, 30, 361-380. [CrossRef]

96. WHO Dashboard. COVID-19 Situation in WHO-Western Pacific Region. 2021. Available online: https://who.maps.arcgis.com/ apps/opsdashboard/index.html\#/345dfdc82b5c4f6a815f1d54a05d18ec (accessed on 13 February 2021).

97. Worldbank. \$30 Million in Support for Tonga's Most Vulnerable. Press Release. 16 December 2020. Available online: https: //www.worldbank.org/en/news / press-release/2020/12/16/30-million-in-support-for-tongas-most-vulnerable (accessed on 13 February 2021).

98. Reliefweb. Tropical Cyclone Harold and COVID-19: A Double Blow to the Pacific Islands. 2020. Available online: https: / / reliefweb.int/report/fiji/tropical-cyclone-harold-and-covid-19-double-blow-pacific-islands (accessed on 13 February 2021).

99. Government of Solomon Islands. Rapid Assessment of the Macro and Sectorial Impacts of Flash Floods in the Solomon Islands, April 2014. Government of Solomon Islands and World Bank Group. 2014. Available online: http://documents.worldbank.org/ curated/en/428071468296671081/pdf/956390WP0P15091000PUBLIC00Box391423B0ACS.pdf (accessed on 26 September 2020).

100. Worldbank. International Tourism, Receipts (Current US\$)—Solomon Islands. 2021. Available online: https:/ / data.worldbank. org/indicator/ST.INT.RCPT.CD?locations=SB (accessed on 20 February 2021).

101. Worldbank. Part III. Country Summaries and Key Indicators. 2020. Available online: https://openknowledge.worldbank.org/ bitstream/handle/10986/33477/211565-pt3.pdf?sequence=24\&isAllowed=y (accessed on 16 February 2021).

102. Diedrich, A.; Aswani, S. Exploring the potential impacts of tourism development on social and ecological change in the Solomon Islands. Ambio 2016, 45, 808-818. [CrossRef]

103. Aswani, S.; Diedrich, A.; Currier, K. Planning for the Future: Mapping Anticipated Environmental and Social Impacts in a Nascent Tourism Destination. Soc. Nat. Resour. 2015, 28, 703-719. [CrossRef]

104. Keen, M.; McNeil, A. After the Floods: Urban Displacement, Lessons from Solomon Islands; Australian National University: Canberra, Australia, 2016.

105. Trustrum, N.A.; Whitehouse, I.E.; Blaschke, P.M. Flood and landslide hazard, northern Guadalcanal, Solomon Islands. Dsir Land Soil Sci. Contract Rep. 1989, 89, 7 .

106. Shortus, M.; Musto, J.; Bugoro, H.; Butafa, C.; Sio, A.; Joshua, C. Vector-control response in a post-flood disaster setting, Honiara, Solomon Islands, 2014. West. Pac. Surveill. Response J. 2016, 7, 38-43. [CrossRef] [PubMed]

107. Ellison, J.C. How South Pacific mangroves may respond to predicted climate change and sea-level rise. In Climate Change in the South Pacific: Impacts and Responses in Australia, New Zealand, and Small Island States, 289-300; Springer: Dordrecht, The Netherlands, 2020; pp. 289-300.

108. Albert, S.; I Saunders, M.; Roelfsema, C.M.; Leon, J.X.; Johnstone, E.; MacKenzie, J.R.; Hoegh-Guldberg, O.; Grinham, A.R.; Phinn, S.R.; Duke, N.C.; et al. Winners and losers as mangrove, coral and seagrass ecosystems respond to sea-level rise in Solomon Islands. Environ. Res. Lett. 2017, 12, 094009. [CrossRef] 
109. Warren-Rhodes, K.; Schwarz, A.-M.; Boyle, L.N.; Albert, J.; Agalo, S.S.; Warren, R.; Bana, A.; Paul, C.; Kodosiku, R.; Bosma, W.; et al. Mangrove ecosystem services and the potential for carbon revenue programmes in Solomon Islands. Environ. Conserv. 2011, 38, 485-496. [CrossRef]

110. UN. World Economic Situation and Prospects 2019; United Nations Publications: New York, NY, USA, 2019.

111. Eisenstein, B. Klimawandel und Tourismus: Opfer oder Täter? In Tourismusatlas Deutschland, 120-121; Eisenstein, B., Schmudde, R., Eilzer, C., Eds.; UVK: Konstanz, Germany, 2016.

112. Keener, V.W.; Marra, J.J.; Finucane, M.L.; Spooner, D.; Smith, M.H. (Eds.) Climate Change and Pacific Islands: Indicators and Impacts. In Report for the 2012 Pacific Islands Regional Climate Assessment; Island Press: Washington, DC, USA, 2012; Available online: https:/ / www.cakex.org/sites/default/ files/documents/NCA-PIRCA-FINAL-int-print-1.13-web.form_.pdf (accessed on 10 March 2021).

113. Collins, M.; Knutti, R.; Arblaster, J.; Dufresne, J.-L.; Fichefet, T.; Friedlingstein, P.; Gao, X.; Gutowski, W.J.; Johns, T.; Krinner, G.; et al. Long-term Climate Change: Projections, Commitments and Irreversibility. In Climate Change 2013: The Physical Science Basis; Contribution of Working Group I to the Fifth Assessment Report of the Intergovernmental Panel on Climate, Change; Stocker, T.F., Qin, D., Plattner, G.-K., Tignor, M., Allen, S.K., Boschung, J., Nauels, A., Xia, Y., Bex, V., Midgley, P.M., Eds.; Cambridge University Press: Cambridge, UK; New York, NY, USA, 2013.

114. Duvat, V.K.E. A global assessment of atoll island planform changes over the past decades. Wiley Interdiscip. Rev. Clim. Chang. 2019, 10, e557. [CrossRef]

115. Holdaway, A.; Ford, M.; Owen, S. Global-scale changes in the area of atoll islands during the 21st century. Anthropocene 2021, 33, 100282. [CrossRef]

116. IPCC. Global Warming of $1.5^{\circ} \mathrm{C}$. An IPCC Special Report on the Impacts of Global Warming of $1.5^{\circ} \mathrm{C}$ above Pre-Industrial Levels and Related Global Greenhouse Gas Emission Pathways. In The Context of Strengthening the Global Response to the Threat of Climate Change, Sustainable Development, and Efforts to Eradicate Poverty; Masson-Delmotte, V., Zhai, P., Pörtner, H.-O., Roberts, D., Skea, J., Shukla, P.R., Pirani, A., Moufouma-Okia, W., Péan, C., Pidcock, R., et al., Eds.; Intergovernmental Panel on Climate Change: Geneva, Switzerland, 2018.

117. CMEP. Pacific Marine Climate Change Report Card 2018. Commonwealth Marine Economies Programme. 2018. Available online: https://climateanalytics.org/media/cefas_pacific_islands_report_card_final_amended_spreads_low-res.pdf (accessed on 20 February 2021).

118. Barnett, J. Climate Change and Food Security in the Pacific Islands. In Food Security in Small Island States; Connell, J., Lowitt, K., Eds.; Springer: Singapore, 2019.

119. Lebel, L. Local knowledge and adaptation to climate change in natural resource-based societies of the Asia-Pacific. Mitig. Adapt. Strat. Glob. Chang. 2012, 18, 1057-1076. [CrossRef]

120. Cashman, A.; Nagdee, M.R. Impacts of Climate Change on Settlements and Infrastructure in the Coastal and Marine Environments of Caribbean Small Island Developing States (SIDS), Caribbean Marine Climate Change Report Card. Sci. Rev. 2017, 155-173. Available online: https://assets.publishing.service.gov.uk/government/uploads/system/uploads/attachment_data/file/60 5066/11._Settlements_and_Infrastructure_combined.docx.pdf (accessed on 20 February 2021).

121. Kumar, L.; Gopalakrishnan, T.; Jayasinghe, S. Impacts of Climate Change on Coastal Infrastructure in the Pacific. In Economic Evaluation of Climate Change Impacts; Springer: Cham, Germany, 2020; pp. 275-294.

122. Wong, P. Coastal Protection Measures-Case of Small Island Developing States to Address Sea-level Rise. Asian J. Environ. Ecol. 2018, 6, 1-14. [CrossRef]

123. McNamara, K.E.; Clissold, R.; Westoby, R.; Piggott-McKellar, A.E.; Kumar, R.; Clarke, T.; Namoumou, F.; Areki, F.; Joseph, E.; Warrick, O.; et al. An assessment of community-based adaptation initiatives in the Pacific Islands. Nat. Clim. Chang. 2020, 10, 628-639. [CrossRef]

124. Charan, D.; Kaur, M.; Singh, P. Customary Land and Climate Change Induced Relocation-A Case Study of Vunidogoloa Village, Vanua Levu, Fiji. In Climate Change Adaptation in Pacific Countries; Springer: Berlin/Heidelberg, Germany, 2017; pp. 19-33.

125. Moreno, A. Mediterranean Tourism and Climate (Change): A Survey-Based Study. Tour. Hosp. Plan. Dev. 2010, 7, 253-265. [CrossRef]

126. Nicholls, S.; Amelung, B. Implications of Climate Change for Rural Tourism in the Nordic Region. Scand. J. Hosp. Tour. 2015, 15, 48-72. [CrossRef]

127. Bischof, M.; Schmude, J.; Bauer, M. Tourismus und Klimawandel—Eine nachfrageseitige Analyse zu Wahrnehmung und Reaktion am Beispiel der Alpen. Z. Tour. 2017, 9, 221-247. [CrossRef]

128. Scherle, N. Im Spannungsfeld von Klimawandel, Overtourism und Agenda 2030: Tourismus in Destinationen des Globalen Südens. In Die Agenda 2030 als Magisches Vieleck der Nachhaltigkeit: Systemische Perspektiven (199-229); Herlyn, E., Lévy-Tödter, M., Eds.; Springer Gabler: Wiesbaden, Germany, 2020.

129. Schipper, E.; Eriksen, S.; Carril, L.F.; Glavovic, B.; Shawoo, Z. Turbulent transformation: Abrupt societal disruption and climate resilient development. Clim. Dev. 2020, 1-8. [CrossRef]

130. O'Brien, $\mathrm{K}$. Is the $1.5^{\circ} \mathrm{C}$ target possible? Exploring the three spheres of transformation. Curr. Opin. Environ. Sustain. 2018, 31, 153-160. [CrossRef] 
131. Rosenbloom, D.; Markard, J. A COVID-19 recovery for climate. Science 2020, 368, 447. [CrossRef] [PubMed]

132. UNWTO (2020). Impact of COVID-19 on Global Tourism Made Clear as UNWTO Counts the Cost of Standstill. 28 July 2020. Available online: https:/ / www.unwto.org/taxonomy/term/347 (accessed on 9 September 2020). 